\title{
TSGA10 wt Allele
}

National Cancer Institute

\section{Source}

National Cancer Institute. TSGA10 wt Allele. NCI Thesaurus. Code C111923.

Human TSGA10 wild-type allele is located in the vicinity of $2 q 11.2$ and is approximately $158 \mathrm{~kb}$ in length. This allele, which encodes testis-specific gene 10 protein, may be involved in the formation of the fibrous sheath of the sperm tail. 